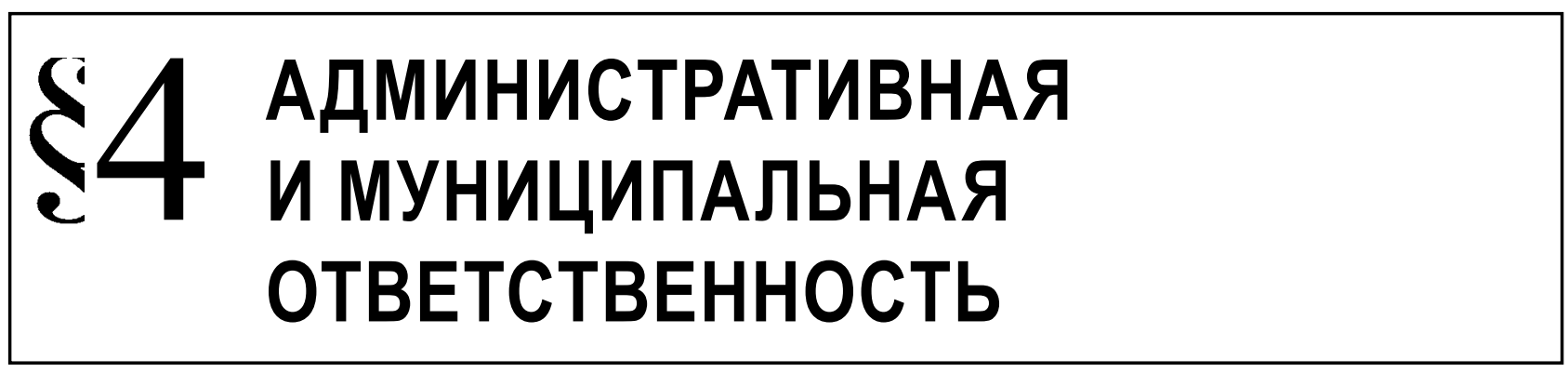

Трофимова Г.А.

\title{
КОНСТИТУЦИОННО-ПРАВОВАЯ ОТВЕТСТВЕННОСТЬ ОРГАНОВ И ДОЛЖНОСТНЫХ ЛИЦ МЕСТНОГО САМОУПРАВЛЕНИЯ: ПРОБЛЕМЫ ТЕОРИИ И ПРАВОВОЙ РЕГЛАМЕНТАЦИИ
}

\begin{abstract}
Аннотация. Органы и должностные лица местного самоуправления являются низовым звеном управления в системе государства, и их ответственность за свою деятельность служит непосредственной и реальной гарантией надлежащего исполнения обязанностей. Конституционно-правовая ответственность является одним из видов ответственности, которая может быть применена к указанным субъектам. И от того, каким образом осуществлено правовое регулирование данного вида ответственности, зависит как уровень самостоятельности местного самоуправления, так и степень возможности приведения к ответственности соответствующих органов и должностных лиц. С целью анализа основных положений конституционно-правовой ответственности органов и должностных лиц местного самоуправления и было проведено данное исследование. При рассмотрении поставленных вопросов автором были использованы общенаучные и частноправовые методы познания, в частности, логический, формально-юридический, сравнительный, системный. В результате проведенной работы было определено соотношение понятий «ответственность органов и должностных лиц местного самоуправления», "муниципально-правовая ответственность» и "конституционно-правовая ответственность»; выявлены проблемы установления содержания конституционного правонарушения и включения тех или иных мер в качестве мер конституционно-правовой ответственности, создана модель наиболее целесообразной диффреренциации видов ответственности в системе местного самоуправления.

Ключевые слова: конституционно-правовая ответственность, ответственность органов власти, ответственность должностных лиц, глава муниципального образования, ответственность представительного органа, муниципально-правовая ответственность, удаление в отставку, ответственность перед населением, ответственность перед государством, самостоятельность местного самоуправления.

Abstract. Local government bodies and officials are the lower tiers within the state system; their responsibility for their activities is a direct and real guarantee of a proper performance of obligations. Constitutional responsibility is one of the forms of responsibility which can be applied to these subjects. Both the level of independence of local governments, and the possibility of imposition of liability on local government bodies and officials depend on the legal regulation of this form of responsibility. The research is aimed at the analysis of the general provisions of constitutional responsibility of local government bodies and officials. The author applies general scientific and specific legal methods of cognition, including the logical, technical, comparative, and system methods. The author defines the correlation of the concepts "responsibility of local government bodies and officials", "municipal legal liability", and "constitutional responsibility"; reveals the problems of defining the content of constitutional offence and considering particular measures as the measures of constitutional responsibility; creates the model of a reasonable differentiation of forms of responsibility within the system of local government.

Key words: constitutional responsibility, responsibility of authorities, responsibility of officials, chief of a municipal unit, responsibility of a representative body, municipal legal responsibility, dismissal, responsibility to the citizens, responsibility to the state, independence of local government, constitutional responsibility, responsibility of the authorities, responsibility of officials, the head of the municipality, responsibility of the representative body, municipal liability, dismissal resigned, responsibility to the people, responsibility to the state, local government autonomy.
\end{abstract}

K онституционно-правовая ответственность пронизывает различные уровни власти, в том числе обеспечивает охрану отношений в сфере местного самоуправления. Вместе с тем име-

ющееся на сегодняшний день правовое регулирование носит несовершенный характер, существует неоднозначное понимание определения самой ответственности органов и должностных лиц мест- 


\section{Административное и муниципальное право 3 (99) • 2016}

ного самоуправления. Поэтому представляется вполне оправданным остановиться на ключевых вопросах ответственности в системе местного самоуправления, рассмотреть основные элементы регулируемой нормами конституционного права ответственности.

Определение ответственности органов и должностных лиц местного самоуправления. В научной литературе выработано несколько подходов к определению ответственности органов и должностных лиц местного самоуправления.

Во-первых, это обоснование того, что ответственность органов и должностных лиц местного самоуправления носит конституционно-правовой характер [1, с. 9; 2, с. 9].

Во-вторых, это предположение о том, что за неисполнение обязанностей и злоупотребление правами, органы и должностные лица местного самоуправления несут муниципально-правовую ответственность [3, с. 62-65; 4, с. 6; 5, с. 8].

Правда, сама муниципально-правовая ответственность понимается по-разному. Например, И. А. Алексеев считает, что, так как «муниципальное право является комплексной отраслью права, то и муниципально-правовая ответственность является комплексным институтом юридической ответственности, которая состоит из норм первичных отраслей права и применяется в отношении субъектов публичной власти на муниципальном уровне» [3, с. 62]. И тогда видами ответственности в муниципальных отношениях становятся уголовная, административная, дисциплинарная, гражданско-правовая, конституционная, экологическая, а субъектами ответственности выступают органы местного самоуправления, должностные лица, общественные объединения, население муниципального образования [3, с. 62, 65].

А. А. Кондрашев полагает, что муниципальноправовую ответственность следует считать в качестве неотъемлемой части (разновидности) конституционно-правовой ответственности и отрицает то, что муниципальное право может быть отнесено к самостоятельным отраслям права, поскольку лишено собственного основного метода регулирования, а также очевидной специфики в регулируемых отношениях, основаниях и процедуре применения санкций [6, с. 40].

B-третьих, это указание на то, что формами ответственности органов и должностных лиц местного самоуправления выступает уголовная, административная, дисциплинарная, материальная, а также специальная ответственность, выражающаяся в прекращении полномочий того или иного выборного лица [7, с. 39]. То есть видится наличие дополнительного вида ответственности в связи с появлением новых, не предусмотренных типичны- ми видами ответственности санкций, однако не дается ее определения.

В-четвертых, это предложение о внесении в научный оборот понятия «конституционно-муниципальная ответственность» [8, с. 10]. Такого рода ответственность, по мнению С. А. Солдатова, является межотраслевым видом публично-правовой ответственности органов и должностных лиц местного самоуправления перед населением муниципального образования и государством, наступает в случае возникновения оснований для удаления главы муниципального образования в отставку, когда им не исполняются в течение трех и более месяцев собственные обязанности по решению вопросов местного значения и одновременно не исполняются обязанности по обеспечению осуществления органами местного самоуправления отдельных государственных полномочий, переданных указанным органам федеральными законами и законами субъектов РФ [8, с. 10].

Третий и четвертый подход в определении понятия ответственности органов и должностных лиц местного самоуправления не приводят к точному пониманию как самой ответственности, так и ее места в системе правовых институтов.

Надуманность выделения муниципально-правовой ответственности в качестве самостоятельного вида юридической ответственности достаточно убедительно аргументирует С. Д. Князев: ни один из действующих нормативно-правовых актов не содержит упоминания о муниципально-правовой ответственности (конституционно-правовая легализована Конституционным Судом РФ); ни основания, ни процедура ответственности органов и должностных лиц местного самоуправления перед населением и государством принципиально не отличаются от оснований и процедуры ответственности законодательных (представительных) органов государственной власти и высших должностных лиц субъектов РФ; санкции по отношению к органам государственной власти и органам местного самоуправления схожи; такие меры ответственности, которые применяются к избирательной комиссии муниципального образования в виде расформирования и досрочного прекращения полномочий ее членов характерны для всех избирательных комиссий любого уровня; ответственность в муниципальном праве также как и сама отрасль представлена из норм других отраслей права, состоит из конституционно-правовых, уголовных, административных, гражданско-правовых и дисциплинарных санкций [9, с. 83-84].

Наиболее убедительной является концепция о том, что ответственность органов и должностных лиц местного самоуправления имеет комплексный, а не индивидуальный характер, представляет 
собой комплексный институт, в котором по предметному признаку объединены разнообразные по своей природе правовые нормы - нормы конституционного, административного, муниципального, гражданского и других отраслей права [10, с. 48; 11 , с. $11 ; 8$, с. 9-10], то есть является частью комплексной отрасли права - муниципального права.

Наименование данной ответственности в качестве муниципальной или муниципально-правовой либо отсутствие такого наименования не имеет практического значения, так как создание комплексных отраслей обусловлено объединением норм разноотраслевых правовых актов с целью наиболее полного представления об имеющемся правовом статусе субъекта (группы субъектов) в системе его взаимоотношений с другими субъектами, занимающим центральное место в выделенной сфере деятельности. Например, предприниматель является основополагающим субъектом объединения в единую отрасль законодательства или комплексную отрасль права норм, регулирующих его деятельность и получившим наименование предпринимательское право; органы и должностные лица местного самоуправления, население муниципального образования - субъектами, правовое регулирование статуса и взаимоотношений которых послужило созданию такой комплексной отрасли права как муниципальное право.

Но так как термин «муниципальная ответственность» или термин «муниципально-правовая ответственность» чаще всего ассоциируется с ответственностью в системе местного самоуправления в целом, а не только в части, регулируемой нормами конституционного права, то наиболее целесообразным видится проведение параллели между муниципальным правом и муниципальной (как комплексный институт) ответственностью, а не между конституционной ответственностью и муниципальной ответственностью как ее частью.

Ответственность органов и должностных лиц местного самоуправления имеет, безусловно, разноотраслевой характер, и зависит от того, какого вида правонарушение служит основанием для ее наступления.

Нарушение норм конституционного права органами и должностными лицами местного самоуправления предполагает применение к ним положений конституционно-правовой ответственности.

Основания дифференциации ответственности органов и должностных лиц местного самоуправления.

Федеральный закон от 6 октября 2003 г. № 131-Ф3 «Об общих принципах организации местного самоуправления в РФ» [12] (далее - Федеральный закон об общих принципах организации местного самоуправления в РФ) обосновывает возможность привлечения органов и должностных лиц местного самоуправления к ответственности перед такими субъектами как государство, население и физические и юридические лица (ст. 70). Ответственность перед последними традиционно относится к гражданско-правовой ответственности.

Однако нельзя признать такое толкование однозначным.

Ответственность перед государством указывает на возложение ответственности от имени Российской Федерации соответствующими государственными органами, в частности, судом, а ответственность перед населением - на принятие решения населением прямо или опосредованно (через избранный им орган).

Ответственность же перед юридическими и физическими лицами также является ответственностью, налагаемой государственными органами от имени Российской Федерации. Если в результате незаконных действий (бездействия), принятия акта, противоречащего закону, органами и должностными лицами местного самоуправления причиняется имущественный ущерб, он подлежит возмещению за счет казны муниципального образования (ст. 1069 ГК РФ). «Должностное лицо, - как справедливо отмечает А. С. Борисов, - может быть привлечено к материальной ответственности (предусмотренной трудовым законодательством), а также административной, уголовной и т. д., но ни одна из них не является ответственностью перед физическими и юридическим лицами» $[13$, с. 17]. Должностные лица не являются субъектами гражданского права, и с них можно требовать возмещения ущерба только в порядке регресса [13, с. $17 ; 14$, с. 115].

Поэтому предложенное законодателем деление ответственности на ответственность перед государством, населением, физическими и юридическими лицами весьма условно.

Имеет практическое значение для правовой характеристики ответственности органов и должностных лиц местного самоуправления выделение таких ее классических видов как гражданско-правовая, уголовная (не для всех субъектов), административная, дисциплинарная (не для всех субъектов) и конституционно-правовая (за исключением муниципальных служащих).

В качестве основания дифференциации конституционно-правовой ответственности следует учитывать такой критерий как взаимосвязь между субъектом конституционного правонарушения и инстанцией применения ответственности, то есть построены ли отношения между субъектом-правонарушителем и субъектом-применителем мер ответственности на системе представительства либо же вне ее. 


\section{Административное и муниципальное право 3 (99) 2016}

В отношениях представительства один субъект с целью реализации собственных интересов назначает (избирает) на должность другое лицо и потому вправе контролировать деятельность назначенного (избранного), а также применять меры ответственности в случае недолжного исполнения представителем своих обязанностей. Во всех остальных случаях основанием ответственности служит формально определенное правонарушение, а субъектом, выносящим решение о наложении мер ответственности, за исключением мер предупредительного и временно пресекательного характера, должен являться суд.

То есть характер ответственности меняется в зависимости от порядка формирования органа / назначения на должность того или иного лица и образуемых еще до совершения правонарушения отношений между субъектом ответственности и инстанцией ответственности.

Если проанализировать нормы Федерального закона об общих принципах организации местного самоуправления в РФ, то можно отметить, что подлежат ответственности:

1) органы местного самоуправления, депутаты, члены выборных органов местного самоуправления, выборные должностные лица местного самоуправления перед населением (ч. 1 ст. 71);

2) представительный орган местного самоуправления перед законодательным органом государственной власти субъекта РФ (ст. 73);

3) глава муниципального образования и глава местной администрации перед высшим должностным лицом субъекта РФ (ст. 74);

4) глава муниципального образования перед представительным органом местного самоуправления, как избранный представительным органом, так и получивший свою должность в ином порядке (ст. 74.1).

В связи с чем можно усмотреть нарушение некоторых структурных элементов ответственности, так как:

1) может подлежать ответственности перед населением не являющийся выборным, следовательно, не состоящий из представителей населения орган местного самоуправления (ч. 1 ст. 71);

2) может подлежать ответственности перед представительным органом местного самоуправления лицо, не назначавшееся этим органом (ст. 74.1), и, соответственно, не состоящее с ним в отношениях представительства;

3) разрешено применение мер ответственности лицом (органом), не участвовавшем в порядке назначения (формирования) должностного лица (органа) и не состоящее с ним в отношениях власти и подчинения, однако подраз- умевающее иерархическую основу взаимодействия между органами власти регионального и муниципального уровня (ст. 73, 74).

4) решение о констатации факта правонарушения принимается судом, а меры ответственности - иным органом или должностным лицом (ст. 73, 74), хотя именно суд должен определять наказание.

Данные элементы деструкции должны быть исключены, и выстроена четкая и логически ясная система взаимоотношений «субъект правонарушения - инстанция применения ответственности» на основе их взаимосвязи - «представитель и представляемые» или же «независимое лицо и независимый субъект применения ответственности».

В научной литературе выделяются и иные основания для дифференциации ответственности на местном уровне.

Например, по мнению Н. Н. Черногор, ответственность органов и должностных лиц местного самоуправления следует классифицировать не по признаку инстанции ответственности (население, государство, физические и юридические лица), а по признаку интереса, который признается, устанавливается нормами права и охраняется при помощи правовых средств: органы и должностные лица местного самоуправления несут ответственность за нарушение государственных, местных публичных и частных интересов [10, с. 44].

По этому поводу следует заметить, что соотношение публичных и частных интересов указывает на деление ответственности на ту, что регулируется частным правом, и ту, что предусмотрена публичным правом, это приводит к укрупнению квалификационных групп и утрате индивидуализирующих ответственность признаков. Соотношение государственных и местных публичных интересов как оснований для защиты мерами юридической ответственности создает дифференциацию ответственности на основе территориального признака, который, однако, не имеет важного значения для определения как мер, так и иных элементов ответственности.

Еще одним видом ответственности называется внутрикорпоративная ответственность, которая, как предполагается, возникает в каждом отдельном муниципальном образовании между органами местного самоуправления, между органами и должностными лицами местного самоуправления, а также внутри органов местного самоуправления $[14$, с. 116]. Как указывает В. С. Кашо, наличие такого вида ответственности «обусловливается необходимостью обеспечивать эффективную работу органов и должностных лиц местного самоуправления не только с помощью внешнего воздействия - со стороны государства или населения, но и с по- 
мощью внутреннего механизма «сдержек и противовесов» $[14$, с. 116$]$.

Однако нельзя не заметить, что понятие «внутрикорпоративная ответственность» можно по аналогии применить и к другим уровням власти - федеральному и региональному, и такая дифференциация ведет к закрытости, узости взаимоотношений между органами власти одного уровня и, чаще всего, не только к подконтрольности одного органа власти другому, но и подчиненности, а такой вариант с точки зрения разделения властей недопустим.

Внутрикорпоративная ответственность больше служит целям осуществления дисциплинарной ответственности, то есть ответственности между работниками, иными лицами, обязанными исполнять предписания органа, в котором они осуществляют свою деятельность, и этим органом. На муниципальном уровне вполне применима внутрикорпоративная дисциплинарная ответственность депутатов перед представительным органом, членов контролирующего органа перед контролирующим органом.

По мнению В. В. Авилова, удаление в отставку является еще одной разновидностью конституционно-правовой ответственности органов и должностных лиц местного самоуправления - ответственностью перед муниципальным образованием [15, c. 48].

Но так как при удалении в отставку главы муниципального образования решение принимается представительным органом власти муниципального образования, а представительный орган - это орган, состоящий из народных избранников, то в данном случае речь может идти об опосредованном характере ответственности перед населением муниципального образования, что вписывается в выше приведенную систему ответственности в зависимости от типа взаимоотношений с субъектом, обладающим правом налагать меры ответственности.

Существенное значение имеет вопрос о предоставлении федеральным законодателем муниципальным образованиям права по определению видов ответственности органов и должностных лиц местного самоуправления и регулирование ее наступления, так как становится неясно, о каких видах идет речь; к тому же вряд ли у муниципальных образований есть возможность добавить какой-то новый вид ответственности, неизвестный федеральному законодателю [14, с. 97].

Следует согласиться с тем, что на муниципальном уровне возможно регулирование ответственности одних субъектов местного самоуправления перед другими субъектами местного самоуправления (органами и должностными лицами местного самоуправления), а также населением, но никак не ответственность перед государством или физическими и юридическими лицами [14, с. 97-98].

Основание ответственности вне системы представительства (перед государством).

Правовым основанием применения мер конституционно-правовой ответственности является нарушение норм конституционного права.

Однако содержание конституционного правонарушения применительно к органам и должностным лицам местного самоуправления исследователями представляется по-разному. В частности, называется:

1) противоправная деятельность органа власти или противоправное поведение должностного лица местного самоуправления, которая привела к однократному существенному, систематическому или массовому нарушению основ конституционного строя, конституционных прав и свобод гражданина и человека [1, с. 10];

2) совершение действия или бездействия, повлекших причинение вреда населению, что признано судом [8, с. 21].

3) привлечение должностного лица к уголовной, административной или дисциплинарной ответственности [7, с. 46];

4) вступление в отношении главы муниципального образования в законную силу обвинительного приговора суда, отвечающего определенным требованиям относительно вида преступления, за которое осуждено лицо, а также назначенного ему в связи с этим наказания (в частности, если обвинительный приговор предусматривает в качестве наказания лишение права занимать определенные должности или заниматься определенной деятельностью, лишение свободы на определенный срок, пожизненное лишение свободы или смертную казнь) [16, с. 44].

5) совершение преступления, предусмотренного гл. 30 УК «Преступления против государственной власти, интересов государственной службы и службы в органах местного самоуправления»; преступления, субъектом которого может быть только должностное лицо; преступления, совершенного лицом с использованием своего должностного положения [16, с. 44];

6) длительное (например, более шести месяцев) уклонение депутатов (или их части) от проведения заседаний [9, с. 86-87];

7) неназначение муниципальной избирательной комиссией в установленные ею сроки соответствующих выборов [9, с. 86-87];

8) нарушение Конституции РФ и законов [6, с. 2122];

9) нарушение Конституции РФ, федеральных законов, законодательства субъектов РФ, устава муниципального образования [17, с. 15]; 


\section{Административное и муниципальное право 3 (99) • 2016}

10) принятие ненормативных правовых актов [17, c. 15];

11) неоднократное издание правовых актов, не соответствующих законодательству, повлекших нарушение прав населения муниципального образования, не учитывающих его интересы, сложившиеся исторические и иные местные традиции [8, с. 12];

12) систематическое издание незаконных нормативных актов, впоследствии своевременно отменяемых представительным органом местного самоуправления $[18$, с. 7$]$;

13) ненадлежащее осуществление переданных государственных полномочий [2, с. 10]; действие (ненадлежащее исполнение) либо бездействие (неисполнение) переданных государственных полномочий [19, с. 11].

14) неисполнение решений органов государственной власти, не связанных с признанием нормативных актов местного представительного органа не соответствующими закону [18, с. 7].

15) злоупотребление или превышение полномочий (в первом случае правонарушитель незаконно, вопреки публичным интересам использует предоставленные ему полномочия, а во втором - совершает действия, явно выходящие за пределы его компетенции) [20, с. 143].

То есть в качестве основополагающего признака правонарушения на муниципальном уровне выбирается либо указание на нарушаемый акт, либо состав деяния по общей схеме - действие и бездействие или через систему прав и обязанностей - ненадлежащее исполнение обязанностей, неисполнение переданных полномочий и т. д., либо упоминается в качестве обязательного признака еще и наличие причиненного вреда, притом массового характера; либо приводится в качестве основания конституционного деликта совершение иного рода правонарушения как поступка, несовместимого с сохранением статуса лица, занимающего должность в органах местного самоуправления.

Все это указывает на пока еще отсутствующее классическое (обоснованное теоретически и выверенное временем практически) определение конституционного деликта и его содержания.

Федеральным законом об общих принципах организации местного самоуправления в РФ, в частности, установлены достаточно краткие основания ответственности перед государством:

1) факт неисполнения решения суда, подтвержденный в судебном порядке (ст. 73);

2) непринятие мер по исполнению решения суда (ст. 74);

3) решения, действия (бездействие), повлекшие (повлекшее) наступление финансовых правонарушений, служащих основанием для вре- менного исполнения отдельных полномочий органов местного самоуправления органами государственной власти (п. 1 ч. 2 ст. 74.1);

4) неисполнение в течение трех месяцев и более обязанностей по решению вопросов местного значения, переданных государственных полномочий (п. 2 ч. 2 ст. 74.1);

5) неудовлетворительная оценка деятельности главы муниципального образования представительным органом муниципального образования по результатам его ежегодного отчета перед представительным органом муниципального образования, данная два раза подряд (п. 3 ч. 2 ст. 74.1);

6) несоблюдение ограничений и запретов и неисполнение обязанностей, которые установлены Федеральным законом от 25 декабря 2008 года N 273-Ф3 «0 противодействии коррупции» и другими федеральными законами (п. 4 ч. 2 ст. 74.1);

7) допущение главой муниципального образования, местной администрацией, иными органами и должностными лицами местного самоуправления муниципального образования и подведомственными организациями массового нарушения государственных гарантий равенства прав и свобод человека и гражданина в зависимости от расы, национальности, языка, отношения к религии и других обстоятельств, ограничения прав и дискриминации по признакам расовой, национальной, языковой или религиозной принадлежности, если это повлекло нарушение межнационального и межконфессионального согласия и способствовало возникновению межнациональных (межэтнических) и межконфессиональных конфликтов (п. 5 ч. 2 ст. 74.5).

При сравнении доктринальных и законодательных положений можно сделать вывод, что пока нет единства позиций между учеными и законодателем по поводу ответственности органов и должностных лиц местного самоуправления.

К числу более упорядоченных оснований конституционно-правовой ответственности органов и должностных лиц местного самоуправления можно отнести определение того, нарушение норм какого уровня может служить основанием для применения мягких форм наказания (например, предупреждения), а какого - жестких форм наказания (в частности, роспуска или отрешения от должности); в каких случаях необходимо учитывать признак «систематичности» нарушения и что под ним понимать; как соотносятся между собой совершение лицом преступления и назначение ему такой меры наказания как отрешение от должности, то есть конституционно-правовой меры ответственности. 
Как представляется, совершение преступления (причем любого) должно стать основанием для отрешения главы муниципального образования от должности и прекращения деятельности депутата. Совершение же ряда административных деликтов может стать условием для вынесения предупреждения о несоответствии занимаемой должности, а при их систематичности - о прекращении полномочий. То есть основанием для привлечения к конституционно-правовой ответственности в данном случае нужно считать деяние, не совместимое с должностью в системе местного самоуправления, в этом заключается отличие уголовно-правового, административного и конституционного деликтов.

Основания ответственности в системе народного представительства (перед населением).

Федеральным законом об общих принципах организации местного самоуправления в РФ предоставлено право муниципальным образованиям самим определять в уставе основания и порядок решения вопросов относительно ответственности перед населением (ч. 1 ст. 71). Поэтому они вольны использовать любую правовую формулу.

Анализируя имеющееся муниципальное правотворчество, С. Г. Гуркова обращает внимание на слишком широкое основание для применения процедуры отзыва, установленное в уставах муниципальных образований. В них могут содержаться нормы, дублирующие положения Федерального закона об общих принципах организации местного самоуправления в РФ; нормы, закрепляющие такое общее основание как нарушение законодательства РФ и субъектов РФ, муниципальных правовых актов; нормы, ограничивающие сферу совершения муниципального правонарушения рамками осуществления должностных полномочий; нормы, устанавливающие в качестве обязательного такой признак объективной стороны муниципального правонарушения, как последствия в виде причиненного материального ущерба; нормы, устанавливающие в качестве основания для отзыва неисполнение (ненадлежащее исполнение) депутатских полномочий; нормы, устанавливающие в качестве основания осуществление деятельности, не совместимой с имеющимся у субъекта статусом; нормы, устанавливающие в качестве основания для отзыва издание нормативно-правового акта, противоречащего Конституции РФ, федеральному законодательству, законодательству субъектов РФ, уставу муниципального образования; нормы, устанавливающие в качестве основания для отзыва нарушение срока издания муниципального правового акта, необходимого для реализации решения, принятого населением на местном референдуме; нормы, устанавливающие иные основания для отзыва, в том числе посредством использования иных деликтов - административных правонарушений, преступлений, например, совершение уголовно наказуемых действий как основание для отзыва [20, с. 141-142].

По ее мнению, основание для отзыва должно быть ограничено рамками осуществления должностных полномочий, кроме того, речь должна идти не о всяком нарушении правовых норм, а только о систематическом или однократном грубом; под систематическим нарушением же следует понимать совершение правонарушения два и более раза, а под однократным грубым - повлекшее последствия в виде нарушения прав и свобод граждан и (или) значительного материального ущерба для муниципального образования [20, с. 143].

Как нам представляется, необходимо согласиться с теми учеными, кто считает верным в качестве основания отзыва выборных лиц признать неудовлетворение интересов населения [21, с. 9]. Назначенные от имени населения его представители - будь то глава муниципального образования или депутаты муниципального уровня, имеют перед собой одну задачу - осуществлять свою деятельность таким образом, чтобы она была направлена на удовлетворение интересов избравшего их населения. Поэтому, отзывая то или иное должностное лицо со своего поста, избиратели должны руководствоваться тем, насколько, с их точки зрения, должным образом, выполняются их наказы, учитывается их мнение. Такое основание должно стать единым и быть закреплено в Федеральном законе об общих принципах организации местного самоуправления в РФ; в уставах муниципальных образований следовало бы устанавливать уже основания инициации проведения процедуры отзыва.

Нарушение законодательства (в широком смысле слова) должно влечь ответственность, предусмотренную нормами права и налагаемую в судебном порядке, то есть перед государством как представителем всего общества, а не перед мало сведущими в правовых основаниях ответственности и составе правонарушения избирателями.

Кроме отзыва возможно применение и иных форм ответственности органов местного самоуправления, депутатов и выборных лиц местного самоуправления перед населением [14, с. 65]. В частности, в уставах муниципальных образований закрепляются такие формы как выражение недоверия представительному органу местного самоуправления, выражение недоверия главе муниципального образования или отдельному депутату, отчеты депутатов и выборных должностных лиц перед населением [14, с. 72-73]. Однако отчеты депутатов - это не форма ответственности, а форма контроля за деятельностью выборных лиц, а выражение недоверия можно признать в качестве 


\section{Административное и муниципальное право 3 (99) • 2016}

предупредительной санкции к правонарушителю, ее применение, как видится, возможно в виде электронного голосования, то есть посредством современных средств связи.

Процедура реализации конституционноправовой ответственности. Федеральным законом об общих принципах организации местного самоуправления в РФ инстанции применения ответственности разделены на две группы - одни констатируют факт нарушения правовой нормы, другие возлагают меры ответственности (ст. ст. 7374). Но не всегда это является обоснованным.

Такой подход можно считать логичным только в том случае, если основанием применения ответственности становится неисполнение судебного решения, которым на правонарушителя была возложена дополнительная обязанность, направленная на восстановление нарушенного правового положения (например, принять новый нормативный акт, внести изменения в действующий нормативный акт, объявить заседание несостоявшимся и т. д.).

В ином случае одного судебного решения должно быть достаточно. И потому можно, например, согласится с А. В. Кузько в том, что ответственность представительного органа местного самоуправления должна наступать на основании решения соответствующего суда; именно суд должен принимать решение о роспуске представительного органа местного самоуправления в связи с обращением к нему с таким требованием высшего должностного лица субъекта РФ [1, с. 22-23].

Еще одной проблемой правового регулирования процедуры конституционной ответственности является нарушение принципа независимости и самостоятельности местного самоуправления в связи с правом органов государственной исполнительной власти инициировать применение к правонарушителю мер ответственности и по собственному усмотрению возлагать их [22, с. 39-40; 23, с. 11]. Причем возможность применения ответственности за ряд правонарушений вообще оставляется лишь за органами исполнительной власти вышестоящего уровня.

В Конституции РФ провозглашен принцип самостоятельности местного самоуправления (ст. ст. $130,131)$, поэтому любое законодательное положение, направленное на установление вертикали исполнительной власти, ведущей к подчинению муниципальных органов власти региональным, неправомерно.

В связи с чем необходимо ликвидировать систему принятия решения о прекращении полномочий органа или выборного должностного лица местного самоуправления органом исполнительной власти вышестоящего уровня.
Высшему должностному лицу субъекта РФ (руководителю высшего исполнительного органа государственной власти субъекта РФ), а также законодательному органу государственной власти субъекта РФ можно предоставить право на обращение в суд с целью констатации факта совершения выборным должностным лицом или органом местного самоуправления правонарушения, назначения ему меры ответственности; а также право на применение предупредительных и временно (до принятия решения соответствующим судом) пресекательных мер.

Кроме того, следует согласиться с предложением о предоставлении права на обращение в суд с требованием досрочного прекращения полномочий органа или выборного должностного лица местного самоуправления населению муниципального образования [8, с. 11], например, через инициативную группу.

Другой проблемой реализации конституционно-правовой ответственности на местном уровне, по мнению В. В. Авилова, является отсутствие в системе местного самоуправления ответного равновесия в части, касающейся взаимной ответственности главы муниципального образования и его представительного органа, а потому предлагается наряду с ответственностью главы муниципального образования перед представительным органом закрепить ответственность представительного органа перед главой муниципального образования [2, с. 9].

На наш взгляд, подобное неприемлемо, так как искажает принцип независимости одного органа власти от другого. Какой-то из органов может являться контролирующим, какой-то применяющим меры ответственности, какой-то субъектом ответственности. Это не препятствует, однако, предоставлению права любому органу либо должностному лицу государственной или муниципальной власти обращаться в суд с требованием признания факта совершения органом или должностным лицом местного самоуправления конституционного деликта и применения ответственности.

Меры ответственности. Основными санкциями конституционно-правовой ответственности в соответствии с Федеральным законом об общих принципах организации местного самоуправления в РФ являются: отзыв (ч. 2 ст. 71), роспуск (ст. 73), отрешение от должности (ч. 1 ст. 74), удаление в отставку (ч. 1 ст. 74.1).

Большинство из перечисленных мер ответственности соответствуют, уже можно сказать, классической формуле санкций конституционноправовой ответственности и связаны с ограничением или прекращением полномочий соответствующего субъекта конституционно-правовых 
отношений. И потому появление на муниципальном уровне такой меры ответственности как удаление в отставку, отсутствующей на региональном и федеральном уровне, было встречено исследователями и практиками неоднозначно. И хотя многими специалистами было отмечено как положительный фактор существование дополнительной возможности по прекращению полномочий главы муниципального образования [24, с. 66], тем не менее, всеми, без исключения, был обозначен целый ряд недостатков нововведения. В частности, было указано на то, что:

1) наименование «удаление в отставку» является спорным [24, с. 66] или даже неудачным (например, по отношению к судьям данное понятие трактуется как почетный уход с должности) $[25$, с. 27];

2) произошло расширение пределов государственного вмешательства в дела местного самоуправления, что несет в себе потенциальную угрозу демократическим основам Российского государства, так как нарушает конституционный принцип самостоятельности местного самоуправления [24, с. 67; 26, с. 69];

3) произошло смешение двух видов ответственности - ответственности перед населением (конституционно-правовой, уголовной) и ответственности перед государством (муниципальноправовой), хотя очевидно, что для разных видов ответственности должны быть разные основания, процедуры, санкции [23, с. 8];

4) отношения между главой муниципального образования и представительным органом являются отражением муниципальных политических конфликтов, а потому принятие решения единолично представительным органом нежелательно [24, с. 68];

5) при формальном соблюдении процедуры удаления в отставку данный механизм фактически используется для сведения счетов; избранному мэру не дают возможность работать, проявить себя (в частности, на практике имеют место случаи удаления глав муниципальных образований в отставку через очень короткий период времени, прошедший с момента их избрания) [23, с. 8];

6) неисполнение обязанностей в течение трех и более месяцев как основание ответственности главы муниципального образования предполагает меньшую ответственность для высшего должностного лица муниципального образования, чем для обычного работника, что вряд ли можно признать верным [24, с. 67];

7) нечетко определено такое основание удаления в отставку как неудовлетворительная оценка деятельности главы муниципального образо- вания по результатам его ежегодного отчета перед представительным органом, данная два раза подряд [24, с. 67; 27, с. 70];

8) неудовлетворительная оценка деятельности главы муниципального образования по результатам его ежегодного отчета, по сути, является основанием политической ответственности [15, с. 49];

9) такое деяние как нецелевое расходование бюджетных средств предусмотрено в качестве основания не только удаления в отставку, но и преступления [24, с. 66];

10) не требуется подтверждения признаков правонарушения судебным решением [23, с. 8].

Как представляется, вместо введения увольнения в отставку должно быть дополнено недостающими основаниями ответственности отрешение главы муниципального образования от должности, и система правонарушений и мер ответственности будет иметь упорядоченный характер.

В научной литературе предлагается ввести и целый ряд дополнительных к имеющимся в ныне действующем законодательстве санкций.

Так, по мнению А. А. Кондрашева, следует добавить такую санкцию как предупреждение в отношении органов и должностных лиц местного самоуправления; санкцией в отношении глав муниципальных образований и представительных органов местного самоуправления может выступить приостановление их деятельности по решению высшего должностного лица и законодательного органа власти субъекта РФ [6, с. 21-22].

Можно согласиться с введением предупредительных и временно (до решения соответствующего судебного органа) пресекательных санкций в отношении главы муниципального образования, предупредительных - в отношении представительного органа местного самоуправления, то есть направленных на оперативное вмешательство в неправовую деятельность, однако не ущемляющих право на самоуправление и гарантирующих независимость органов и должностных лиц муниципального образования.

В результате проведенного исследования можно сделать вывод, что и теоретическое обоснование, и правовое регулирование ответственности органов и должностных лиц местного самоуправления должно получить наиболее четкий характер. Не должно допускаться многозначной интерпретации как самой ответственности на муниципальном уровне, ее видов, так и несистемности в определении оснований, субъектов применения и санкций конституционноправовой ответственности; а также регионального вмешательства в дела местного самоуправления и нивелирования значимости суда в вынесении решений о назначении и применении санкций. 


\section{Библиография:}

1. Кузько А. В. Конституционно-правовая ответственность органов и должностных лиц местного самоуправления перед государством. Автореф. дис. ... канд. юрид. наук. М., 2008.

2. Авилов В. В. Конституционно-правовая ответственность органов и должностных лиц местного самоуправления. Автореф. дис. ... канд. юрид. наук. Белгород, 2011.

3. Алексеев И. А. Содержание и виды муниципально-правовой ответственности // Журнал российского права. 2006. № 9.

4. Красновский М. В. Проблемы юридической ответственности органов и должностных лиц местного самоуправления (теоретико-правовой аспект). Автореф. дис. ... канд. юрид. наук. Санкт-Петербург, 2008.

5. Пономарева В. О. Ответственность органов местного самоуправления и должностных лиц местного самоуправления перед государством: теоретические и правовые аспекты. Автореф. дис. ... канд. юрид. наук. Челябинск, 2006.

6. Кондрашев А. А. Теория конституционно-правовой ответственности в Российской Федерации. Автореф. дис. ... докт. юрид. наук. М., 2011.

7. Яковлев В. В. Вопросы ответственности органов и должностных лиц местного самоуправления перед государством // Сибирский юридический вестник. 2005. № 3.

8. Солдатов С. А. Ответственность органов и должностных лиц местного самоуправления перед населением муниципального образования и государством. Автореф. дис. ... канд. юрид. наук. Ставрополь, 2012.

9. Князев С. Д. Конституционная ответственность в муниципальном праве: вопросы теории и практики // Журнал российского права. 2005. № 6. С. 83-84.

10. Черногор Н. Н. Классификация ответственности (ее виды) органов и должностных лиц местного самоуправления в муниципально-правовой науке // Государство и право. 2007. № 11.

11. Роженцев С. В. Развитие института юридической ответственности органов местного самоуправления и их должностных лиц как формы охраны интересов субъектов малого и среднего предпринимательства (вопросы теории). Автореф. дис. ... канд. юрид. наук. Тюмень, 2011.

12. СПС «КонсультантПлюс».

13. Борисов А. С. Ответственность местного самоуправления и ее виды // Государственная власть и местное самоуправление. 2005. № 2 .

14. Кашо В. С. Ответственность в системе местного самоуправления: Учебное пособие. Красноярск, 2005.

15. Авилов В. В. Некоторые вопросы удаления главы муниципального образования в отставку как меры конституционной ответственности // Вестник Владимирского юридического института. 2011. № 2.

16. Распопин М. Отрешение от должности главы муниципального образования // Законность. 2007. № 10.

17. Виноградов В. А. Конституционно-правовая ответственность: системное исследование. Автореф. дис. ... докт. юрид. наук. М., 2005.

18. Соловьев С. Г. Муниципально-правовая ответственность местного представительного органа: содержание и актуальные проблемы // Государственная власть и местное самоуправление. 2004. № 2.

19. Мокеев М. М. Конституционно-правовая ответственность органов и должностных лиц местного самоуправления. Автореф. дис. ... канд. юрид. наук. Саратов, 2003.

20. Гуркова С. Г. Некоторые проблемы реализации муниципально-правовой ответственности на примере отзыва депутатов, членов выборных органов местного самоуправления, выборных должностных лиц местного самоуправления // Вестник Тюменского государственного университета. 2009. № 2.

21. Дабалаев А. А. Конституционная ответственность органов и должностных лиц местного самоуправления в Российской Федерации. Автореф. лис. ... канд. юрид. наук. М., 2006.

22. Белоновский В. Н. Отрешение от должности главы субъекта Российской Федерации как мера конституционноправовой ответственности // Вестник Российского государственного гуманитарного университета. 2011 . № 8.

23. Шугрина Е. С. Почему механизм удаления глав муниципальных образований в отставку приводит к существенным нарушениям прав на местное самоуправление // Государственная власть и местное самоуправление. 2011. № 5.

24. Соловьев С. Г., Четвергова А. В. К вопросу о содержании правовой конструкции удаления в отставку главы муниципального образования // Конституционное и муниципальное право. 2011. № 5.

25. Чугунова Е. Н. Спорные аспекты института удаления главы муниципального образования в отставку // Проблемы права. 2012. № 5 (36).

26. Давыдова Н. Ю. Институт удаления главы муниципального образования в отставку // Адвокат. 2009 . № 12.

27. Володько И. А. Удаление главы муниципального образования в отставку: предварительные итоги реализации // Конституционное и муниципальное право. 2013. № 1.

\section{References (transliterated):}

1. Kuz'ko A. V. Konstitutsionno-pravovaya otvetstvennost' organov i dolzhnostnykh lits mestnogo samoupravleniya pered gosudarstvom. Avtoref. dis. ... kand. yurid. nauk. M., 2008.

2. Avilov V. V. Konstitutsionno-pravovaya otvetstvennost' organov i dolzhnostnykh lits mestnogo samoupravleniya. Avtoref. dis. ... kand. yurid. nauk. Belgorod, 2011.

3. Alekseev I. A. Soderzhanie i vidy munitsipal'no-pravovoi otvetstvennosti // Zhurnal rossiiskogo prava. 2006 . № 9. 
4. Krasnovskii M. V. Problemy yuridicheskoi otvetstvennosti organov i dolzhnostnykh lits mestnogo samoupravleniya (teoretiko-pravovoi aspekt). Avtoref. dis. ... kand. yurid. nauk. Sankt-Peterburg, 2008.

5. Ponomareva V. O. Otvetstvennost' organov mestnogo samoupravleniya i dolzhnostnykh lits mestnogo samoupravleniya pered gosudarstvom: teoreticheskie i pravovye aspekty. Avtoref. dis. ... kand. yurid. nauk. Chelyabinsk, 2006.

6. Kondrashev A. A. Teoriya konstitutsionno-pravovoi otvetstvennosti v Rossiiskoi Federatsii. Avtoref. dis. ... dokt. yurid. nauk. M., 2011.

7. Yakovlev V. V. Voprosy otvetstvennosti organov i dolzhnostnykh lits mestnogo samoupravleniya pered gosudarstvom // Sibirskii yuridicheskii vestnik. 2005. № 3 .

8. Soldatov S. A. Otvetstvennost' organov i dolzhnostnykh lits mestnogo samoupravleniya pered naseleniem munitsipal'nogo obrazovaniya i gosudarstvom. Avtoref. dis. ... kand. yurid. nauk. Stavropol', 2012.

9. Knyazev S. D. Konstitutsionnaya otvetstvennost' v munitsipal'nom prave: voprosy teorii i praktiki // Zhurnal rossiiskogo prava. 2005. № 6. S. 83-84.

10. Chernogor N. N. Klassifikatsiya otvetstvennosti (ee vidy) organov i dolzhnostnykh lits mestnogo samoupravleniya $\mathrm{v}$ munitsipal'no-pravovoi nauke // Gosudarstvo i pravo. 2007. № 11.

11. Rozhentsev S. V. Razvitie instituta yuridicheskoi otvetstvennosti organov mestnogo samoupravleniya i ikh dolzhnostnykh lits kak formy okhrany interesov sub"ektov malogo i srednego predprinimatel'stva (voprosy teorii). Avtoref. dis. ... kand. yurid. nauk. Tyumen', 2011.

12. SPS «Konsul'tantPlyus».

13. Borisov A. S. Otvetstvennost' mestnogo samoupravleniya i ee vidy // Gosudarstvennaya vlast' i mestnoe samoupravlenie. 2005. № 2 .

14. Kasho V. S. Otvetstvennost' v sisteme mestnogo samoupravleniya: Uchebnoe posobie. Krasnoyarsk, 2005.

15. Avilov V. V. Nekotorye voprosy udaleniya glavy munitsipal'nogo obrazovaniya v otstavku kak mery konstitutsionnoi otvetstvennosti // Vestnik Vladimirskogo yuridicheskogo instituta. 2011. № 2.

16. Raspopin M. Otreshenie ot dolzhnosti glavy munitsipal'nogo obrazovaniya // Zakonnost'. 2007. № 10.

17. Vinogradov V. A. Konstitutsionno-pravovaya otvetstvennost': sistemnoe issledovanie. Avtoref. dis. ... dokt. yurid. nauk. M., 2005.

18. Solov'ev S. G. Munitsipal'no-pravovaya otvetstvennost' mestnogo predstavitel'nogo organa: soderzhanie i aktual'nye problemy // Gosudarstvennaya vlast' i mestnoe samoupravlenie. 2004. № 2.

19. Mokeev M. M. Konstitutsionno-pravovaya otvetstvennost' organov i dolzhnostnykh lits mestnogo samoupravleniya. Avtoref. dis. ... kand. yurid. nauk. Saratov, 2003.

20. Gurkova S. G. Nekotorye problemy realizatsii munitsipal'no-pravovoi otvetstvennosti na primere otzyva deputatov, chlenov vybornykh organov mestnogo samoupravleniya, vybornykh dolzhnostnykh lits mestnogo samoupravleniya // Vestnik Tyumenskogo gosudarstvennogo universiteta. 2009. № 2.

21. Dabalaev A. A. Konstitutsionnaya otvetstvennost' organov i dolzhnostnykh lits mestnogo samoupravleniya v Rossiiskoi Federatsii. Avtoref. lis. ... kand. yurid. nauk. M., 2006.

22. Belonovskii V. N. Otreshenie ot dolzhnosti glavy sub"ekta Rossiiskoi Federatsii kak mera konstitutsionno-pravovoi otvetstvennosti // Vestnik Rossiiskogo gosudarstvennogo gumanitarnogo universiteta. 2011. № 8.

23. Shugrina E. S. Pochemu mekhanizm udaleniya glav munitsipal'nykh obrazovanii v otstavku privodit k sushchestvennym narusheniyam prav na mestnoe samoupravlenie // Gosudarstvennaya vlast' i mestnoe samoupravlenie. 2011 . № 5.

24. Solov'ev S. G., Chetvergova A. V. K voprosu o soderzhanii pravovoi konstruktsii udaleniya v otstavku glavy munitsipal'nogo obrazovaniya // Konstitutsionnoe i munitsipal'noe pravo. 2011. № 5.

25. Chugunova E. N. Spornye aspekty instituta udaleniya glavy munitsipal'nogo obrazovaniya v otstavku // Problemy prava. 2012. № 5 (36).

26. Davydova N. Yu. Institut udaleniya glavy munitsipal'nogo obrazovaniya v otstavku // Advokat. 2009. № 12.

27. Volod'ko I. A. Udalenie glavy munitsipal'nogo obrazovaniya v otstavku: predvaritel'nye itogi realizatsii // Konstitutsionnoe i munitsipal'noe pravo. 2013. № 1. 